\title{
Factors influencing critical and target loads for the acidification of lake-watersheds in the Adirondack region of New York
}

\author{
Qingtao Zhou • Charles T. Driscoll • \\ Timothy J. Sullivan $\cdot$ Afshin Pourmokhtarian
}

Received: 18 October 2014/ Accepted: 16 April 2015/Published online: 8 May 2015

(C) The Author(s) 2015. This article is published with open access at Springerlink.com

\begin{abstract}
Critical loads (CLs) and target loads (TLs) are tools used to guide air emissions control strategies for recovery of forest and aquatic ecosystems impacted by elevated atmospheric deposition. We use the dynamic hydrochemical model-PnET-BGC (photosynthesis evapotranspiration biogeochemical) to evaluate biophysical factors that affect CLs and TLs of acidity for the Constable Pond watershed, as an example of a chronically acidic drainage lake in the Adirondack region of New York, USA. These factors included a range of future scenarios of decreases in atmospheric nitrate, ammonium and sulfate deposition from present to 2200; historical forest harvesting; supply of naturally occurring organic acids; and
\end{abstract}

Responsible Editor: Jacques C. Finlay.

Q. Zhou $(\bowtie) \cdot$ C. T. Driscoll

Department of Civil and Environmental Engineering,

Syracuse University, Syracuse, NY 13244, USA

e-mail: qzhou01@syr.edu

C. T. Driscoll

e-mail: ctdrisco@syr.edu

T. J. Sullivan

E\&S Environmental Chemistry, Corvallis,

OR 97339, USA

e-mail: tim.sullivan@esenvironmental.com

A. Pourmokhtarian

Department of Earth and Environment, Boston University,

Boston, MA 02215, USA

e-mail: apourmok@bu.edu variations in lake hydraulic residence time. Simulations show that decreases in sulfate deposition were more effective in increasing lake acid neutralizing capacity (ANC) than equivalent decreases in nitrate deposition, 4.6 times greater in 2040-2050 but decreasing to 2 times greater by 2200 . Future lake ANC is anticipated to increase to a greater extent when the watershed experiences past forest cutting compared to a scenario without historical land disturbance. Under higher rates of watershed supply of naturally occurring dissolved organic carbon (DOC $\sim 1000 \mu \mathrm{mol} \mathrm{C} / \mathrm{L}$ ), ANC is lower than under relatively low DOC supply $(\sim 100 \mu \mathrm{mol} \mathrm{C} / \mathrm{L})$ due to strongly acidic functional groups associated with dissolved organic matter. Lakes with longer hydrologic residence time exhibit less historical acidification and can achieve a greater ANC from recovery than lakes with shorter hydrologic residence times due to in-lake production of ANC. This study improves understanding of how biogeochemical processes at the landscape level can influence the rate and extent of recovery of lake-watersheds in response to decreases in atmospheric deposition.

Keywords Adirondacks - Acid neutralizing capacity · Acidification · Critical loads (CLs) · Target loads (TLs)

\section{Introduction}

Over the past century, acid deposition has caused environmental impacts across North America, Europe 
and Asia (Driscoll et al. 2010). Acid deposition is mainly a by-product of anthropogenic sulfur dioxide $\left(\mathrm{SO}_{2}\right)$, oxidized $\left(\mathrm{NO}_{x}\right)$, and reduced nitrogen $\left(\mathrm{NH}_{3}\right)$ emissions. Concern over the effects of acid deposition has largely focused on high elevation eastern forested regions, with limited availability of base cations (Greaver et al. 2012). Elevated inputs of acid deposition to acid-sensitive areas contribute to the acidification of naturally acidic (base-poor) soils through the depletion of available nutrient cations (calcium $\left[\mathrm{Ca}^{2+}\right]$, magnesium $\left[\mathrm{Mg}^{2+}\right]$ ), the mobilization of dissolved inorganic aluminum $\left(\mathrm{Al}_{i}\right)$ and the enrichment of soil nitrogen $(\mathrm{N})$ resulting in changes and health impacts to forest vegetation (Driscoll et al. 2001; Juice et al. 2006; Thomas et al. 2009). Acid deposition and associated acidification of soil have also affected surface waters, causing decreases in $\mathrm{pH}$ and acid neutralizing capacity (ANC) and increases in concentrations of $\mathrm{Al}_{i}$, impacting aquatic organisms and communities (Lovett et al. 2009).

The Adirondack region of New York receives relatively high rates of atmospheric sulfur $(\mathrm{S})$ and $\mathrm{N}$ deposition due to elevated $\mathrm{S}$ and $\mathrm{NO}_{x}$ emissions in the eastern U.S. Forest and aquatic ecosystems of the Adirondacks have been impacted by these inputs (Driscoll et al. 2001). Between 1984 and 1987, the Adirondack Lakes Survey sampled 1469 lakes out of a total of 2759 lakes (larger than 0.2 ha). An estimated $26 \%$ of the surveyed lakes had $\mathrm{pH}<5.0,26 \%$ had ANC $<0 \mu \mathrm{eq} / \mathrm{L}$ and $50 \%$ had ANC $<50 \mu \mathrm{eq} / \mathrm{L}$ (Kretser et al. 1989).

In the U.S., $\mathrm{SO}_{2}$ and $\mathrm{NO}_{x}$ emissions have been substantially controlled as a result of the Clean Air Act and associated rules (Driscoll et al. 2010). These air quality management programs have resulted in improvements in surface water chemistry in acidimpacted regions in the eastern U.S., including the Adirondacks (Kahl et al. 2004). Waller et al. (2012) showed that decreases in sulfate $\left(\mathrm{SO}_{4}{ }^{2-}\right)$ and nitrate $\left(\mathrm{NO}_{3}{ }^{-}\right)$wet deposition have coincided with increases in the ANC of Adirondack lakes since the early 1990s.

A "critical load" (CL) is a value of atmospheric deposition below which it will not cause changes in ecosystem structure and function (Nilsson and Grenfelt 1988; Burns et al. 2008). The "target load", also called the dynamic critical load, is the deposition of one or more pollutants that is set to protect natural resources based on policy, economic, or temporal considerations (Porter et al. 2005). CLs depict a steady-state condition, whereas TLs represent dynamic conditions of an ecosystem that is not at steady-state with respect to acid deposition, but rather is changing over time. CLs and TLs are tools used to specify the inputs of air pollutants that ecosystems can sustain without notable impacts on their structure or function.

Previous studies have quantified TLs and CLs for ecosystems and regions, including the Adirondacks (Sullivan et al. 2012; Zhou et al. 2015; Fakhraei et al. 2014). However few investigations have quantified how the biophysical characteristics of the landscape affect the response of lake-watersheds to decreases in atmospheric deposition. The goal of this research was to conduct a case study of the response of an acidimpacted lake-watershed in the Adirondack region of New York, Constable Pond to decreases in atmospheric deposition and to evaluate how lake-watershed characteristics influence this response. For this case study we calculate TLs and CLs for $\mathrm{NO}_{3}{ }^{-}$and $\mathrm{SO}_{4}{ }^{2-}$ deposition, and assess how select biophysical factors including historical forest cutting, the supply of naturally occurring organic acids and lake hydrological residence time (HRT) that influence the lakewatershed response to acidification and recovery. Constable Pond is a chronically acidic drainage lake that has been a site of field and modeling studies (Driscoll et al. 1987, 2007; Chen et al. 2004b). We used the dynamic hydrochemical model-PnET-BGC to: (1) determine the TLs and CLs for $\mathrm{NO}_{3}{ }^{-}$and $\mathrm{SO}_{4}{ }^{2-}$ deposition to Constable Pond watershed, evaluating the tradeoffs of controls on $\mathrm{SO}_{4}{ }^{2-}$ versus $\mathrm{NO}_{3}{ }^{-}$and ammonium $\left(\mathrm{NH}_{4}{ }^{+}\right)$versus $\mathrm{NO}_{3}{ }^{-}$to achieve TL/CLs; and (2) explore the lake-watershed characteristics that affect recovery from $\mathrm{SO}_{4}{ }^{2-}$ and $\mathrm{NO}_{3}{ }^{-}$ deposition, including the supply of naturally occurring organic acids, historical forest cutting disturbance and variations in lake HRT.

\section{Methods}

Study site

Constable Pond $\left(43^{\circ} 50^{\prime} \mathrm{N}, 74^{\circ} 48^{\prime} \mathrm{W}\right)$ is located in the western Adirondacks and is situated in the North Branch of the Moose River (Fig. 1). Constable Pond is a chronically acidic $(\mathrm{ANC}<0)$, thin-till drainage lake, with moderate concentrations of dissolved organic carbon (DOC; $420 \mu \mathrm{mol}$ C/L) [http://www. 


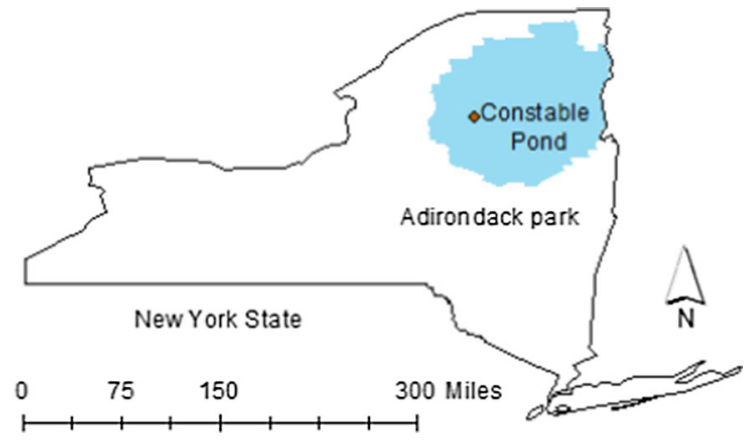

Fig. 1 Location for Constable Pond in New York state

adirondacklakessurvey.org/; 1982-present ( 2008)]. The watershed area is 945 ha. The elevation of Constable Pond is about $584 \mathrm{~m}$. The dominant vegetation type is northern hardwoods, with yellow birch, red spruce, eastern hemlock, red maple, and American beech (Cronan et al. 1987). The mean HRT of the lake (annual water inputs/lake volume) is 0.06 year. Hydrologic residence time is the average time that a water molecule is in the lake basin, and is calculated as the lake volume divided by mass inputs of water from direct precipitation and drainage. Detailed information from Chen et al. (2004b) on the lake and its watershed is available to facilitate model parameterization and testing, including a time-series of water chemistry observations from 1982 to present ( 2008).

\section{PnET-BGC}

PnET-BGC is a comprehensive forest-soil-water model that links a $\mathrm{C}, \mathrm{N}$ and the water balance model PnET-CN (Aber et al. 1997) with a biogeochemical model, BGC (Gbondo-Tugbawa et al. 2001). The model performs well in small, high-elevation forest watersheds, where detailed site data are available to constrain inputs and parameter values, such as this application for Constable Pond (Chen et al. 2004b). Regional scale applications have also been conducted (Chen and Driscoll 2004a; Chen and Driscoll 2005; Zhai et al. 2008).

Input parameters for the model include time series of meteorological data, atmospheric deposition (wet and dry) (Fig. 2), element weathering rates, and landdisturbance history (Table 1). Soil parameters needed for PnET-BGC include soil mass, water holding capacity, cation exchange capacity (CEC), cation exchange constants and anion adsorption constants.
Vegetation is characterized in PnET-BGC using the major forest cover types represented at the study site and the associated element stoichiometry. A thorough description of the model and a detailed sensitivity analysis of the model to inputs and parameter values are provided in Gbondo-Tugbawa et al. (2001) and Pourmokhtarian et al. (2012). Model outputs include monthly fluxes of water and major elements within and from ecosystem compartments, and volumeweighted concentrations of major solutes in lake water. For purposes of this analysis, we primarily used ANC as a critical chemical indicator of the acid-base status of Constable Pond to evaluate CLs and TLs and lake-watershed responses to landscape factors.

Deposition scenarios and model application

We evaluated different scenarios of future atmospheric $\mathrm{NO}_{3}{ }^{-}, \mathrm{NH}_{4}{ }^{+}$and $\mathrm{SO}_{4}{ }^{2-}$ deposition and combinations of these as model inputs. Following previous research (Chen et al. 2004b; Zhai et al. 2008), model runs were initiated for Constable Pond watershed in $1000 \mathrm{AD}$, and run with a monthly time step. At a given time step atmospheric deposition is applied to the watershed and lake surface. Time-dependent reactions proceed (e.g., weathering, vegetation uptake) and then equilibrium reactions are invoked (cation exchange, solution equilibria). Following equilibrium we allow water to drain from the watershed to the lake and from the lake basin to the lake outlet. We assumed constant background deposition (10\% of current atmospheric deposition), meteorological conditions represented as average of available meteorological measurements, and no land disturbance prior to 1850 to achieve steady-state. These assumptions specified "background" (pre-industrial 1850) conditions. Historical changes in atmospheric deposition, meteorology and land disturbance were initiated after 1850 . The model was run from 1850 through 2008 based on a combination of measured values of atmospheric deposition (from 1978 to 2008) extrapolated from detailed observations made at the intensive study site at Huntington Forest $\left(43^{\circ} 58^{\prime} \mathrm{N}, 74^{\circ} 13^{\prime} \mathrm{W}\right)$ and reconstructions of historical deposition from emissions records (1850-1978) following the approach described previously for PnET-BGC applications in the Adirondacks (Driscoll et al. 2001; Chen et al. 2004b; Zhai et al. 2008; Fakhraei et al. 2014). Regression analyses were conducted between measured annual 
Fig. 2 Hindcast and forecast deposition loading scenarios at Constable Pond for $\mathrm{SO}_{4}^{2}$ (a) and $\mathrm{NO}_{3}{ }^{-}$(b)

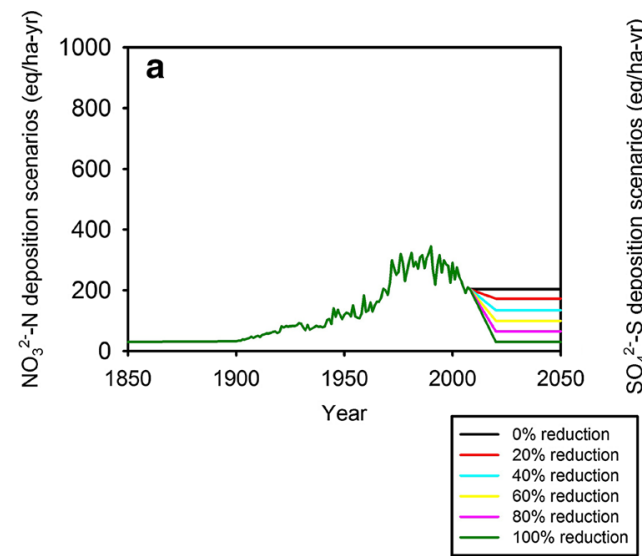

Table 1 Input parameters and data sets for PnET-BGC model

\begin{tabular}{|c|c|c|}
\hline Attributes & Variables & Data sets \\
\hline Watershed & $\begin{array}{l}\text { Areas; Longitude; Latitude; disturbance (logging, fire or storm; year and } \\
\text { intensity and the fraction of the watershed that is disturbed by the event) }\end{array}$ & $\begin{array}{l}\text { Chen et al. 2004, Adirondack } \\
\text { Park Agency }\end{array}$ \\
\hline $\begin{array}{l}\text { Meteorological } \\
\text { (monthly) }\end{array}$ & $\begin{array}{l}\text { Maximum/minimum temperature }\left({ }^{\circ} \mathrm{C}\right) \text {, precipitation quantity }(\mathrm{cm} / \mathrm{month}) \text {, } \\
\text { incident solar radiation }\left(\mathrm{mmol} / \mathrm{m}^{2}-\mathrm{s}\right)\end{array}$ & Adirondack Park Agency \\
\hline $\begin{array}{l}\text { Wet deposition } \\
\text { (monthly) }\end{array}$ & All major solutes & $\begin{array}{l}\text { National Atmospheric } \\
\text { Deposition Program }\end{array}$ \\
\hline $\begin{array}{l}\text { Dry to wet deposition } \\
\text { ratios (monthly) }\end{array}$ & All major solutes & $\begin{array}{l}\text { Clean Air Status and Trends } \\
\text { Network }\end{array}$ \\
\hline Vegetation & $\begin{array}{l}\text { Tree species; vegetation stoichiometry (element, organic content and } \\
\text { element plant tissue), foliar exchange/uptake }\left(\mathrm{H}^{+}, \mathrm{Mg}^{2+}, \mathrm{K}^{+}, \mathrm{Ca}^{2+} \text {, and }\right. \\
\left.\mathrm{NH}_{4}^{+}\right)\end{array}$ & Aber et al. (1997) \\
\hline Soil & $\begin{array}{l}\text { Soil bulk density }\left(\mathrm{kg} / \mathrm{m}^{3}\right) \text {, soil exchangeable cations (eq/kg), soil selectivity } \\
\text { coefficients, adsorbed anions, weathering ( } / \mathrm{m}^{2} \text {-month) }\end{array}$ & $\begin{array}{l}\text { Gbondo-Tugbawa et al. } \\
\text { (2001), Chen et al. (2004) }\end{array}$ \\
\hline
\end{tabular}

volume-weighted concentrations of major solutes in wet deposition at the Huntington Forest National Atmospheric Deposition Program (NADP) site (NY20; 1978-2008) and emissions from the atmospheric source area for the Adirondacks (Zhai et al. 2008; Fakhraei et al. 2014). These regressions were used in conjunction with historical emission estimates (Nizich et al. 1996) to reconstruct wet deposition for the period 1900-1978. For the period 1850-1900 concentrations of solutes in wet deposition were assumed to increase linearly from estimated background values. Measured wet deposition (from NY20; 1978-2008) was used to reconstruct the wet deposition for Constable Pond (1978-2008) based on the empirical spatial models developed by Ito et al. (2002). The dry to wet deposition ratios for base cations, strong acid anions and other elements for Huntington Forest were derived from Shepard et al. (1989). As there were no consistent trends in dry and wet deposition ratios among Clean Air Status and Trends Network (CASTNET) and nearby NADP sites in the northeastern U.S. (http://epa.gov/castnet/javaweb/ index.html), dry to wet deposition ratios for solute inputs were held constant during the simulation period based on previous research (Shepard et al. 1989; Chen et al. 2004b) $\left(\mathrm{SO}_{4}{ }^{2-}: 0.15 ; \mathrm{NO}_{3}{ }^{-}: 0.1 ; \mathrm{Ca}^{2+}: 0.5\right.$; $\left.\mathrm{Mg}^{2+}: 0.5\right)$.

Historical meteorological data for Constable Pond were extrapolated from detailed time series measurements available from the Huntington Forest starting from 1955 (air temperature, precipitation, photosynthetically active radiation (PAR); http://www.esf.edu/ hss/em/huntington/ackerman.html) using empirical spatial models developed by Ito et al. (2002) and a regional regression model for PAR developed by Aber and Freuder (2000). 
For forecasts, model simulations were continued through the year 2200 considering a range of deposition scenarios, decreasing from ambient (2008) deposition to "background" (pre-industrial 1850) deposition $(0,20,40,60,80$ and $100 \%$ reductions $)$ for $\mathrm{NO}_{3}{ }^{-}, \mathrm{NH}_{4}{ }^{+}$and $\mathrm{SO}_{4}{ }^{2-}$, individually and in combination. Future scenarios included a 12-year linear decrease from ambient values to the level of deposition of interest (in 2020) and kept constant at this deposition level through 2200. This range of values was used to evaluate tradeoffs associated with controls in $\mathrm{SO}_{2}, \mathrm{NO}_{x}$ and $\mathrm{NH}_{3}$ emissions to achieve ecosystem recovery from acid deposition. For future scenarios, meteorological conditions were assumed to remain constant as the mean of available measured monthly values. The time series of atmospheric $\mathrm{SO}_{4}{ }^{2-}$ and $\mathrm{NO}_{3}{ }^{-}$deposition used for this analysis is shown in Fig. 2.

\section{Landscape disturbance scenarios}

The Adirondack region has experienced land cover disturbance and land use change over the past 200 years (McNeil et al. 2006). Different types of disturbance, including fire, forest harvest, meteorological events and road construction have occurred.

Unfortunately, historical land disturbance records for specific watersheds in the Adirondacks are limited. McNeil et al. (2006) reconstructed the land disturbance history of the Adirondack region based on the interpretation of historic land disturbance maps assembled by the Adirondack Park Agency. Based on this analysis, it appears that there was an extensive clear-cut in Constable Pond watershed around 1900. For the base case hindcast projection, we assumed that cutting occurred in 1900, impacting $60 \%$ of the watershed with removal of $80 \%$ of the logged tree biomass.

To evaluate the influence of historical land disturbance on past and potential future changes in surface water ANC, we considered two hypothetical land disturbance scenarios, in addition to the base case. An intensive harvest scenario involved an extensive clearcut in 1950 and again in 1995, with the cut occurring on $60 \%$ of the watershed and removal of $80 \%$ of the aboveground biomass (Table 2). The base case and this intense cutting scenario are compared with an additional scenario which assumed no historical land disturbance.
Supply of naturally occurring organic acids

Dissolved organic matter (DOM) in forest soil and surface waters is mainly derived from humified organic matter formed from plant material (Zsolnay 1996; Kalbitz et al. 2000). In PnET-BGC, a fraction of soil organic matter is mineralized and converted to DOM that can be mobilized from soil with drainage water. Dissolved organic matter is represented in the model as an organic acid analog with the ability to protonate/deprotonate and complex Al (Driscoll et al. 1994; Gbondo-Tugbawa and Driscoll 2001). For Constable Pond, the mean DOC over the period of record was $420 \mu \mathrm{mol} \mathrm{C} / \mathrm{L}$. To examine the role of DOC supply in regulating the acid-base status of Adirondack lakes, two scenarios of lake DOC were considered in addition to the base case. The fraction of soil organic matter that is decomposed to DOC was: (1) increased such that the lake DOC concentration was $905 \mu \mathrm{mol} \mathrm{C} / \mathrm{L}$, indicative of elevated DOC waters; and (2) decreased such that the lake DOC concentration was $125 \mu \mathrm{mol} \mathrm{C} / \mathrm{L}$, indicative of low DOC waters (Driscoll et al. 1994).

In-lake $\mathrm{SO}_{4}{ }^{2-}$ and $\mathrm{NO}_{3}{ }^{-}$retention

The production of ANC can occur by in-lake retention of $\mathrm{SO}_{4}{ }^{2-}$ and $\mathrm{NO}_{3}{ }^{-}$. In PnET-BGC, the removal of $\mathrm{NO}_{3}{ }^{-}$and $\mathrm{SO}_{4}{ }^{2-}(\mathrm{R})$ by in lake-processes is depicted as a mass transfer expression proposed by Kelly et al. (1987):

$R_{s}=\frac{S}{\left(\bar{Z} / \tau_{\mathrm{w}}\right)+S}$

where $\bar{z}$ is the mean depth of the lake; $\tau_{\mathrm{w}}$ is the HRT; and $\mathrm{S}$ is the mass transfer coefficient for $\mathrm{SO}_{4}{ }^{2-}$ or $\mathrm{NO}_{3}{ }^{-}$. The removal of $\mathrm{SO}_{4}{ }^{2-}$ and $\mathrm{NO}_{3}{ }^{-}$is determined by HRT and lake depth and mass transfer coefficients for $\mathrm{SO}_{4}{ }^{2-}$ and $\mathrm{NO}_{3}{ }^{-}$. Constable Pond has a relatively short HRT (0.06 year) and in-lake processes do not strongly influence the neutralization of acid deposition and the acid-base status of the lake. However, some lakes in the Adirondacks have longer HRT (up to several years; http://www.adirondacklakessurvey.org/) and change in in-lake ANC production may be an important consideration for recovery of some Adirondack lakes from acid deposition. To evaluate the potential importance of in-lake processes, we considered three hypothetical scenarios of HRT for 
Table 2 Hypothetical land disturbance scenarios for Constable Pond watershed

\begin{tabular}{llll}
\hline Event & Year & Percent of land area cut & Percent of biomass removal \\
\hline 1 & 1900 & 0.6 & 0.8 \\
2 & 1950 & 0.6 & 0.8 \\
& 1995 & 0.6 & 0.8 \\
3 & None & None & None \\
\hline
\end{tabular}

Constable Pond in the PnET-BGC simulations: 0.06, 0.6 and 6 years, assuming the lake depth remains constant.

\section{Computation methods}

We evaluated the effectiveness of decreases in $\mathrm{SO}_{4}{ }^{2-}$ and $\mathrm{NO}_{3}{ }^{-}$deposition to obtain a given level of $\mathrm{ANC}$ at steady-state (CLs) and under dynamic conditions (2040-2050; TLs). To evaluate the interplay between changes in $\mathrm{SO}_{4}{ }^{2-}$ and $\mathrm{NO}_{3}{ }^{-}$deposition and resulting lake ANC, we projected lake ANC using PnET-BGC under different loadings of $\mathrm{SO}_{4}{ }^{2-}$ and $\mathrm{NO}_{3}{ }^{-}$individually and in combination. From the model output under different loads of $\mathrm{NO}_{3}{ }^{-}$and $\mathrm{SO}_{4}{ }^{2-}$ deposition for a given time interval (i.e., 2040-2050, 2150-2200), we interpolated ANC values to develop ANC isopleths to illustrate the responsiveness of Constable Pond ANC to variations $\mathrm{SO}_{4}{ }^{2-}$ and $\mathrm{NO}_{3}{ }^{-}$ deposition. ANC isopleths are figures of equivalent values of lake ANC under different conditions of $\mathrm{SO}_{4}{ }^{2-}$ deposition on the $\mathrm{x}$-axis in combination with $\mathrm{NO}_{3}{ }^{-}$deposition on the $y$-axis that are developed for a given period. These values were obtained from interpolation of model simulations for different combinations of $\mathrm{SO}_{4}{ }^{2-}$ and $\mathrm{NO}_{3}{ }^{-}$deposition for the period of interest. We developed $\mathrm{SO}_{4}{ }^{2-}-\mathrm{NO}_{3}{ }^{-}$deposition isopleths to examine the relative effectiveness of equivalent decreases in atmospheric $\mathrm{SO}_{4}{ }^{2-}$ and $\mathrm{NO}_{3}{ }^{-}$ deposition in accomplishing increases in the ANC for Constable Pond. One isopleth depicts CL conditions of ANC for when the lake-watershed is at quasi steadystate with respect to the lower inputs of atmospheric deposition (2150-2200) and the second shows a TL condition for a near term period that might be more relevant to the time-scale of management decisions (2040-2050).

We evaluated the agreement between model simulations and observed water chemistry data using normalized mean error (NME) and normalized mean absolute error (NMAE) (Janssen and Heuberger 1995). These metrics can be calculated as follows:

$N M E=\frac{\bar{p}-\bar{o}}{\bar{o}} ; N M A E=\frac{\sum_{t=1}^{n}\left(\left|p_{t}-o_{t}\right|\right)}{n \bar{o}}$

where $p_{t}$ is the projected value at time $\mathrm{t} ; o_{t}$ is the observed value at time $\mathrm{t} ; \bar{o}$ and $\bar{p}$ are the average observed and projected values over time $t$; and $n$ is the number of observations. NME represents the offset between the simulation result and the observation. NMAE represents the absolute offset between the simulation result and observation. Negative values for NME indicate that projected values are lower than observations; positive values for NME indicate that the projected values exceed observations.

We also conducted a sensitivity analysis of projections of state variables ANC and percent base saturation (\% BS) in Constable Pond to model inputs and parameter values, including $\mathrm{SO}_{4}{ }^{2-}$ and $\mathrm{NO}_{3}{ }^{-}$deposition, soil mass, site density, $\mathrm{SO}_{4}{ }^{2-}$ adsorption capacity, carbon dioxide partial pressure $\left(\mathrm{P}_{\mathrm{CO} 2}\right)$, and CEC. The sensitivity analysis was calculated as follows:

$S_{\text {Param }, x}=\frac{\partial X / X}{\partial_{\text {Parm }} /{ }_{\text {Parm }}}$

where $\mathrm{X}$ is the state variable; Param is the model input parameters. The higher the values of $S_{\text {Param }, x}$, the more sensitive is the model simulation to the state variables (Gbondo-Tugbawa et al. 2001).

\section{Results}

Model results, sensitivity analysis and time series of model hindcast and forecast projections of lake chemistry

In general, PnET-BGC reproduces the time series of lake chemistry for Constable Pond over the period 
since measurements were initiated in 1982 (Fig. 3; Table 3). Simulations show a continuous decrease in lake $\mathrm{SO}_{4}{ }^{2-}$ concentrations, which is consistent with estimated decreases in atmospheric $S$ deposition input to the model. The agreement between measured and model simulated $\mathrm{SO}_{4}{ }^{2-}$ is good (NME 0.0048; NMAE 0.073) (Table 3). In contrast, PnET-BGC captures the absolute value of lake $\mathrm{NO}_{3}{ }^{-}$(NME 0.058 ; mean measured $28 \mu \mathrm{mol} / \mathrm{L}$ vs. modeled $30 \mu \mathrm{mol} / \mathrm{L} \mathrm{NO}_{3}{ }^{-}$), but fails to depict all of the year-to-year variation in annual $\mathrm{NO}_{3}{ }^{-}$concentrations (NMAE 0.44) (Fig. 3; Table 3). Previous efforts have shown the challenge of

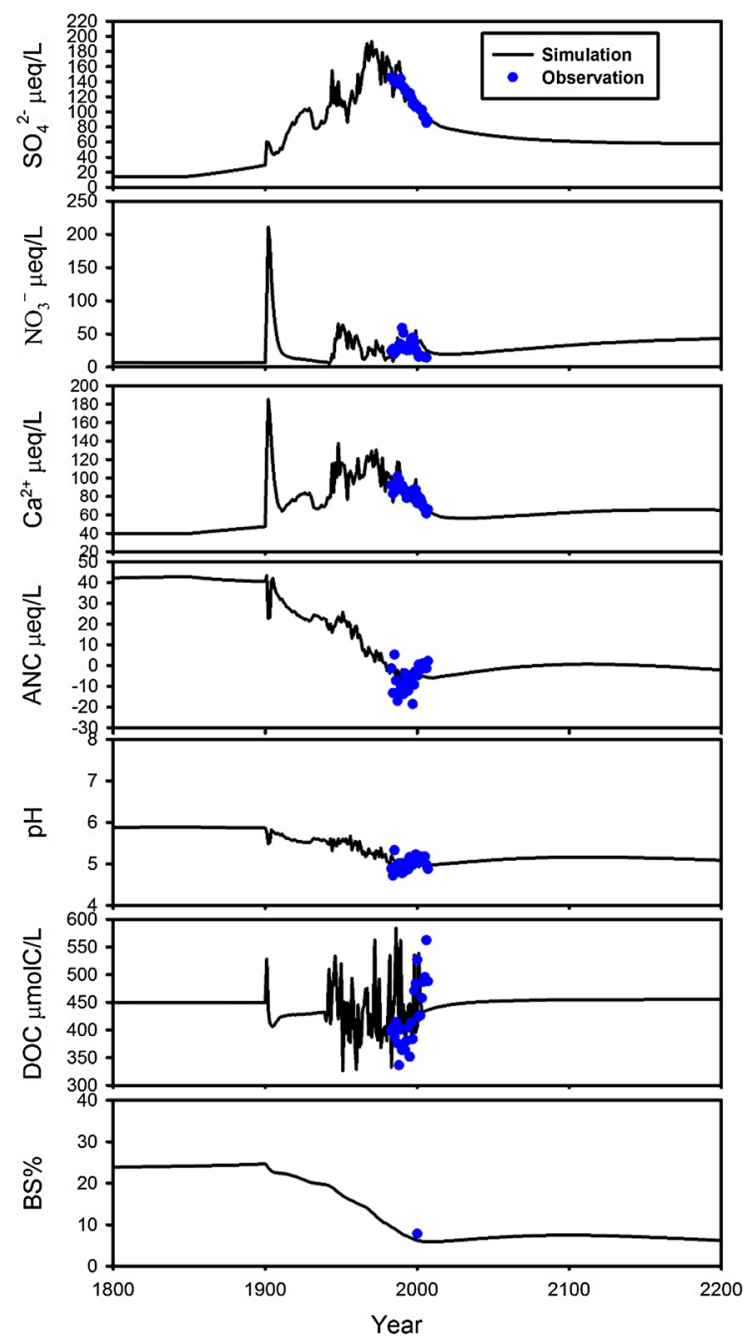

Fig. 3 Long term model simulations of $\mathrm{SO}_{4}{ }^{2-}, \mathrm{NO}_{3}{ }^{-}, \mathrm{Ca}^{2+}$, ANC, pH, and DOC in lake-water and \% BS in soil at Constable Pond from 1800 to 2200. The future deposition for the model input is hypothesized as the same as the average of deposition over the period 2004-2008 and is kept constant for model simulation (2008-2200) simulating forest ecosystem $\mathrm{N}$ dynamics and $\mathrm{NO}_{3}{ }^{-}$ loss due to sensitivity of the $\mathrm{N}$ cycle to meteorological variation and uncertainty in historical land disturbance (Chen et al. 2004b; Pourmokhtarian et al. 2012).

PnET-BGC effectively captures the magnitude and trends of lake $\mathrm{Ca}^{2+}$ (NME 0.054, NMAE 0.074) (Fig. 3; Table 3). The model is also able to simulate the magnitude of ANC (NME -0.37), pH (NME 0.0024) and DOC (NME 0.046) (Fig. 3; Table 3). NME values are probably not a good metric for model agreement with lake ANC due to values near $0 \mu \mathrm{eq} / \mathrm{L}$. Nevertheless, the mean modeled ANC for Constable Pond over the monitoring period $(-6.2 \mu \mathrm{eq} / \mathrm{L})$ is similar to the measured value $(-4.0 \mu \mathrm{eq} / \mathrm{L})$. The model under-predicts the increase in measured ANC observed in recent years (Fig. 3) and does not depict the increase in DOC observed in Constable Pond in response to decreases in acid deposition (Driscoll et al. 2007). Time series data for soil chemistry are not available for Constable Pond watershed, but the model simulates the single measurement of soil BS (measured soil \% BS $7.8 \%$ vs. modeled $6.4 \%$; Table 3). Accurate projections of $\mathrm{pH}$ and ANC with PnET-BGC require effective simulation of concentrations and trends in all major solutes, as these are used to calculate $\mathrm{pH}$ and ANC in the model (GbondoTugbawa et al. 2001).

We evaluated the sensitivity analysis of projections of ANC and \% BS to variation in model inputs and parameters (Table 4). The range of changes in different inputs and parameters used for this analysis was $\pm 10 \%$ of current values. For example, $\mathrm{S}^{\text {(ANC) }}$ and $\left.\mathrm{S}^{(\%} \mathrm{BS}\right)$ for $\mathrm{SO}_{4}{ }^{2-}$ deposition are -2.6 and -1.2 , respectively. If $\mathrm{SO}_{4}{ }^{2-}$ deposition is increased by $10 \%$ of current deposition, ANC decreases by $26 \%$ of the current value, while soil base saturation is projected to decrease by $12 \%$ of the current value. Model projections of $\mathrm{ANC}$ and $\% \mathrm{BS}$ are found to be sensitive to $\mathrm{SO}_{4}{ }^{2-}$ wet deposition, $\mathrm{NO}_{3}{ }^{-}$wet deposition, $\mathrm{P}_{\mathrm{CO} 2}$, CEC, and soil mass, which is consistent with a previous sensitivity analysis by GbondoTugbawa et al. (2001).

Long-term model hindcasts suggests that in 1850, prior to the advent of acid deposition, the acid-base status of Constable Pond was considerably different than current conditions. Projections of pre-industrial (before 1850) $\mathrm{SO}_{4}{ }^{2-}(15 \mu \mathrm{eq} / \mathrm{L})$ and $\mathrm{NO}_{3}{ }^{-}(5 \mu \mathrm{eq} / \mathrm{L})$ are considerably lower and ANC (43 $\mu \mathrm{eq} / \mathrm{L}), \mathrm{pH}(5.9)$ and soil \% BS (22\%) are considerably higher than 
Table 3 Simulated and observed mean values for different chemical species in Constable Pond over the monitoring period 1983-2007

\begin{tabular}{llllllll}
\hline Chemical species & $\mathrm{Ca}^{2+}(\mu \mathrm{eq} / \mathrm{L})$ & $\mathrm{SO}_{4}{ }^{2-}(\mu \mathrm{eq} / \mathrm{L})$ & $\mathrm{NO}_{3}{ }^{-}(\mu \mathrm{eq} / \mathrm{L})$ & $\mathrm{ANC}(\mu \mathrm{eq} / \mathrm{L})$ & $\mathrm{pH}$ & $\mathrm{DOC}(\mu \mathrm{mol} \mathrm{C} / \mathrm{L})$ & $\mathrm{BS}(\%)$ \\
\hline Simulation & 86 & 120 & 30 & -4.0 & 5.02 & 442 & 6.4 \\
Observation & 81 & 120 & 28 & -6.2 & 5.01 & 423 & 7.8 \\
NME & 0.054 & 0.0048 & 0.058 & -0.37 & 0.0024 & 0.046 \\
NMAE & 0.074 & 0.073 & 0.44 & -0.95 & 0.029 & 0.16 \\
\hline
\end{tabular}

NME normalized mean error, NMAE normalized mean absolute error

Table 4 Sensitivity analysis of simulated ANC and \% BS for Constable Pond in response to variability in selected parameters

\begin{tabular}{llll}
\hline Parameter & Range & $\mathrm{S}^{\text {(ANC) }}$ & $\mathrm{S}^{(\% \mathrm{BS})}$ \\
\hline Sulfate wet deposition (eq/ha-year) & $290.3-365.7$ & -2.6 & -1.2 \\
Nitrate wet deposition (eq/ha-year) & $172.5-233.5$ & -0.64 & -0.4 \\
Soil mass $\left(\mathrm{kg} / \mathrm{m}^{2}\right)$ & $465.7-630.1$ & -0.3 & 0.3 \\
$\mathrm{SO}_{4}{ }^{2-}$ adsorption capacity (mmol/g) & $3.6-36$ & 0.01 & $<0.01$ \\
$\mathrm{CEC}(\mathrm{kmolc} / \mathrm{ha})$ & $139-181$ & 0.8 & 1.2 \\
Site DOC $(\mathrm{mol} / \mathrm{mol} \mathrm{c})$ & $0.015-0.030$ & 0.02 & 0.1 \\
Log $\left(\mathrm{P}_{\mathrm{CO} 2}\right)$ & $1.5-2.5$ & 0.27 & -0.77 \\
\hline
\end{tabular}

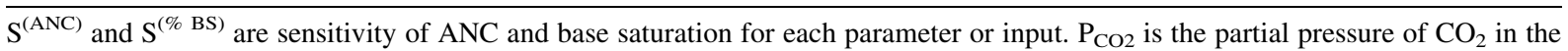
soil. The units for $\mathrm{P}_{\mathrm{CO} 2}$ is mol fraction

both measured and model calculated values for Constable Pond today (Fig. 3). The trajectory of the model hindcast from 1850 to the present shows increases in lake $\mathrm{SO}_{4}{ }^{2-}$ that closely follow the pattern of reconstruction of the time series of atmospheric $\mathrm{SO}_{4}{ }^{2-}$ deposition, with a peak around 1975, and marked declines in recent years due to controls on emissions associated with the Clean Air Act. Simulated lake $\mathrm{NO}_{3}{ }^{-}$concentrations are low in the 1800 s. There is a peak in lake $\mathrm{NO}_{3}{ }^{-}$in 1900 due to simulation of the cutting event that affected lake water chemistry for a short period (with associated increases in $\mathrm{Ca}^{2+}$ and DOC, decreases in ANC and $\mathrm{pH}$ ). Following recovery from the clear-cut, lake $\mathrm{NO}_{3}{ }^{-}$increases in the mid 1900s associated with the maturation of the forest in the watershed coupled with increases in atmospheric $\mathrm{NO}_{3}{ }^{-}$and $\mathrm{NH}_{4}{ }^{+}$deposition. Unlike $\mathrm{SO}_{4}{ }^{2-}$, lake $\mathrm{NO}_{3}{ }^{-}$does not closely follow changes in atmospheric $\mathrm{N}$ deposition due to strong vegetation and soil retention and ecosystem $\mathrm{N}$ cycling which is sensitive to year-to-year variation in meteorological conditions.

Concentrations of lake $\mathrm{Ca}^{2+}$, the major base cation, closely match concentrations of strong acid anions $\left(\mathrm{SO}_{4}{ }^{2-}, \mathrm{NO}_{3}{ }^{-}\right)$, largely resulting from displacement from soil cation exchange sites. Note that the mobilization of $\mathrm{Ca}^{2+}$ and $\mathrm{Mg}^{2+}$ (values not shown) coincides with the loss of cations from the soil exchanger (soil percent base saturation; \% BS) and soil acidification during the last century. Coincident with the mobilization of $\mathrm{SO}_{4}{ }^{2-}$ and $\mathrm{NO}_{3}{ }^{-}$are decreases in ANC from 43 to $-4 \mu \mathrm{eq} / \mathrm{L}$ and $\mathrm{pH}$ from 5.9 to 5.0 .

$\mathrm{ANC}$ and $\% \mathrm{BS}$ in response to future $\mathrm{S}$ or $\mathrm{N}$ reduction scenarios

Calculations using PnET-BGC suggest that decreases in atmospheric $\mathrm{SO}_{4}{ }^{2-}$ deposition are effective in increasing the ANC and soil \% BS of acid impacted lake-watersheds in the Adirondacks, such as Constable Pond. Model simulations indicate that following the hypothetical decreases in atmospheric $\mathrm{SO}_{4}{ }^{2-}$ deposition by 2020 (Fig. 2) there is a marked initial decrease in $\mathrm{SO}_{4}{ }^{2-}$ concentrations until the lake reaches steady-state with respect to the new inputs. In response to these changes, there are initially rapid rates of ANC increase, with ANC increases diminishing over time and approach steady-state around 2150-2200 (Fig. 4). Under the different scenarios of 
decreases in atmospheric $\mathrm{SO}_{4}{ }^{2-}$ deposition of 0,20 , $40,60,80$ and $100 \%$, projected ANC values are -2.3 , $3.2,8.9,13.9,18.8$ and $21.9 \mu \mathrm{eq} / \mathrm{L}$, respectively at quasi steady-state (i.e., 2150-2200) (Fig. 4). These represent rates of lake ANC increase of 0.02, 0.05, $0.08,0.10,0.13$ and $0.15 \mu \mathrm{eq} / \mathrm{L}$-year, respectively, over the forecast period (2020-2200) (Fig. 4).

We also explored the response of soil \% BS to hypothetical future changes in atmospheric deposition. The results of model simulations of $\% \mathrm{BS}$ illustrate one of the challenges to recovery of forest ecosystems from acid deposition. From the current modeled soil \% BS of $6.4 \%$, the model projections suggest future $\%$ BS ranging from a slight decrease to $6.2 \%$ under the $0 \%$ deposition decrease scenario to an increase to $15.3 \%$ under a $100 \%$ decrease in atmospheric $\mathrm{SO}_{4}{ }^{2-}$ deposition at steady state (2150-2200) (Fig. 4). Even after complete elimination of anthropogenic $\mathrm{SO}_{4}{ }^{2-}$ deposition for nearly 200 years, model simulations suggest that soil \% BS will not recover to estimated pre-industrial conditions $(\sim 22 \%)$.

Decreases in atmospheric $\mathrm{N}$ deposition are less effective in recovering ANC than an equivalent $\mathrm{SO}_{4}{ }^{2-}$ deposition. Under scenarios of 0, 20, 40, 60, 80 and $100 \%$ decreases in atmospheric $\mathrm{NO}_{3}{ }^{-}$deposition, steady-state values of ANC are projected to be -2.3 ,
$-0.49,1.6,3.4,5.1$ and $6.7 \mu \mathrm{eq} / \mathrm{L}$ respectively (Fig. 4). Under the $\mathrm{NO}_{3}{ }^{-}$deposition control scenarios, the rate of lake ANC increase is 0.02, 0.03, 0.04, 0.05, 0.06 and $0.07 \mu$ eq/L-year, respectively over the simulation period. Soil \% BS also responded over the simulation period, ranging from slight continued decrease in soil \% BS to $6.2 \%$ under a $0 \%$ decrease in $\mathrm{NO}_{3}{ }^{-}$deposition to an increase to $\% \mathrm{BS}=10 \%$ under a scenario of $100 \%$ elimination of anthropogenic $\mathrm{NO}_{3}{ }^{-}$deposition.

We developed $\mathrm{SO}_{4}{ }^{2-}-\mathrm{NO}_{3}{ }^{-}$deposition isopleths to examine the relative effectiveness of decreases in atmospheric $\mathrm{SO}_{4}{ }^{2-}$ and $\mathrm{NO}_{3}{ }^{-}$deposition in accomplishing increases in the ANC of Constable Pond (Fig. 5). A few observations are evident from these isopleths. There are combinations of $\mathrm{SO}_{4}{ }^{2-}$ and $\mathrm{NO}_{3}{ }^{-}$ deposition at which positive ANC can be achieved for Constable Pond. However, an equivalent decrease in atmospheric $\mathrm{SO}_{4}{ }^{2-}$ deposition is more effective in achieving a unit increase in ANC than an equivalent decrease in atmospheric $\mathrm{NO}_{3}{ }^{-}$deposition. The slope of ANC for the parallel lines on the $\mathrm{NO}_{3}-\mathrm{SO}_{4}$ isopleth for the 2040-2050 period is about 4.6, but at steadystate this slope decreases to about 2 (Fig. 5). This pattern suggests that decreases in $\mathrm{SO}_{4}{ }^{2-}$ deposition are about 4.6 times more effective than equivalent decreases in $\mathrm{NO}_{3}{ }^{-}$deposition for 2040-2050, to
Fig. 4 Long term simulations of $\mathrm{NO}_{3}{ }^{-}$, $\mathrm{SO}_{4}{ }^{2-}$, ANC and soil \% BS in response to past and different future scenarios of $\mathrm{NO}_{3}{ }^{-}, \mathrm{SO}_{4}{ }^{2-}$ deposition at Constable Pond
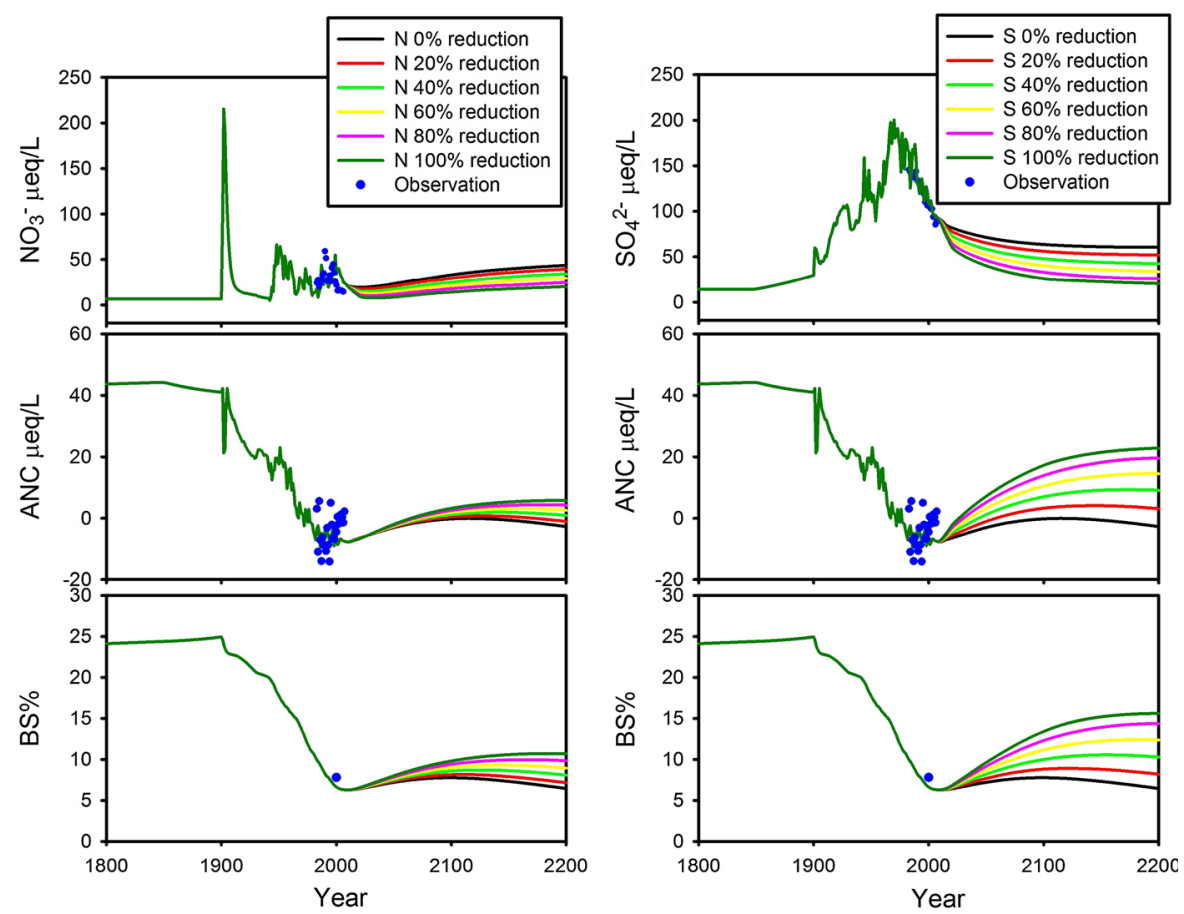
achieve equivalent increases of ANC. With time as the forest matures and the watershed is less able to retain $\mathrm{N}$ inputs, the extent of $\mathrm{NO}_{3}{ }^{-}$leaching increases. Under these conditions decreases in atmospheric $\mathrm{N}$ deposition becomes more effective in achieving increases in ANC, thus the slope of the isopleth decreases as the lake-watershed approaches steadystate. However, at steady-state the lake ANC is projected to increase $0.11 \mu \mathrm{eq} / \mathrm{L}$ for every eq/ha-year decrease in $\mathrm{SO}_{4}{ }^{2-}$ deposition, but only increase $0.06 \mu \mathrm{eq} / \mathrm{L}$ for every eq/ha-year decrease in $\mathrm{NO}_{3}{ }^{-}$ deposition (Fig. 5).

We also examined the degree to which relative changes in $\mathrm{NH}_{4}{ }^{+}$and $\mathrm{NO}_{3}{ }^{-}$deposition influence lake ANC. In theory, atmospheric deposition of $\mathrm{NH}_{4}{ }^{+}$ followed by a given quantity of plant uptake and $\mathrm{NO}_{3}{ }^{-}$ leaching should decrease surface water ANC to a greater extent than the equivalent quantity of $\mathrm{NO}_{3}{ }^{-}$ (van Breemen et al. 1983). Indeed simulations with PnET-BGC suggest that decreases in atmospheric $\mathrm{NO}_{3}{ }^{-}$deposition $(0.049 \mu \mathrm{eq} / \mathrm{L} / \mathrm{eq} / \mathrm{ha})$ are somewhat more effective in achieving increases in ANC than equivalent decreases in $\mathrm{NH}_{4}{ }^{+}$deposition $(0.034 \mu \mathrm{eq} /$ L/eq/ha).

\section{Historical land disturbance effects}

Model simulations were conducted to evaluate the effects of hypothetical historical land disturbance on future recovery of Constable Pond under decreases in $\mathrm{NO}_{3}{ }^{-}$or $\mathrm{SO}_{4}{ }^{2-}$ deposition (i.e., 0, 20, 40, 60, 80 and $100 \%$ decreases). In 1900, the initial loss of ANC under the no-historical land disturbance scenario is slightly delayed compared with the base case simulation which involves a forest harvesting in 1900. However, through the 20th Century, there is limited difference between the base case and the nohistorical land disturbance. The minimum ANC ( -10 $\mu \mathrm{eq} / \mathrm{L}$ ) occurs around 2005 for both scenarios, with a slightly lower \% BS under the base-case $(5.5 \%)$ than the no-historical land disturbance scenario $(6.5 \%)$ due to the removal of base cations in harvested forest vegetation and leaching losses from soil exchanger associated with the historical clear-cut in 1900 (Fig. 6).

Under the potential future decreases in atmospheric $\mathrm{NO}_{3}{ }^{-}$or $\mathrm{SO}_{4}{ }^{2-}$ deposition, the condition of no historical forest disturbance is projected to recover slightly less ANC than the base case scenario. For example, under the no historical disturbance condition at steady-state (i.e., 2200), if $\mathrm{NO}_{3}{ }^{-}$deposition is decreased to pre-industrial values (Fig. 1), ANC values are projected to increase to $3.1 \mu \mathrm{eq} / \mathrm{L}$, slightly lower than the ANC achieved under the base case scenario (5.7 $\mu \mathrm{eq} / \mathrm{L})$ (Fig. 5). If $\mathrm{SO}_{4}{ }^{2-}$ deposition is decreased to pre-industrial values under the no historical land disturbance scenario, ANC values are projected to increase to $19.8 \mu \mathrm{eq} / \mathrm{L}$, again lower than the ANC achieved under the base case scenario (29.8 $\mu \mathrm{eq} / \mathrm{L}$ ) (Fig. 6).

The contrasting scenario is a more intense forest disturbance scenario, with two clear-cuts occurring in 1950 and again in 1995. Simulations show pulses of decreased ANC immediately following the cuts associated with short-term elevated leaching losses of $\mathrm{NO}_{3}{ }^{-}$. These decreases are short-lived (a few years), but the long-term effects of repeated cutting disturbance causes much more severe historical
Fig. 5 Isopleths of ANC for 2150-2200 (a) and for 2040-2050 (b) at Constable Pond showing the combinations of total $\mathrm{SO}_{4}{ }^{2-}$ and $\mathrm{NO}_{3}{ }^{-}$deposition that result in projected values of ANC. $X$ axes and $Y$ axes represent total $\mathrm{SO}_{4}{ }^{2-}$ and $\mathrm{NO}_{3}{ }^{-}$deposition, respectively
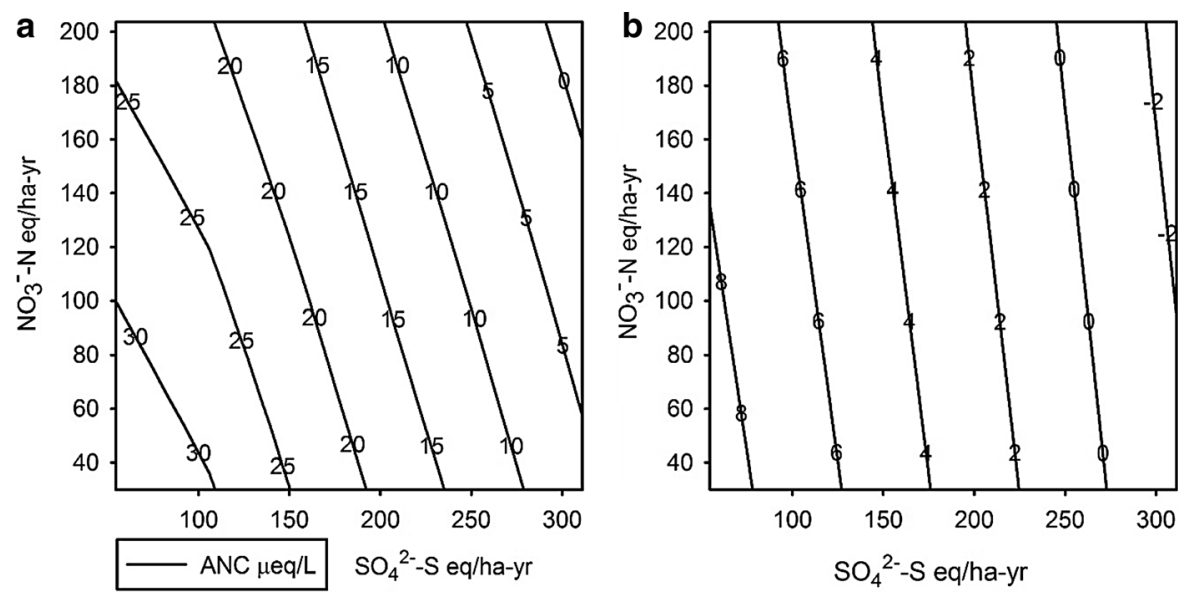
Fig. 6 Simulations of ANC for Constable Pond from 1800 to 2200 under three hypothetical land disturbance scenarios (1900 land disturbance; no forest harvesting; 1950 and 1995 land disturbance) in response to past and hypothetical future decreases in $\mathrm{NO}_{3}{ }^{-}$(a) and $\mathrm{SO}_{4}{ }^{2-}$ (b) deposition

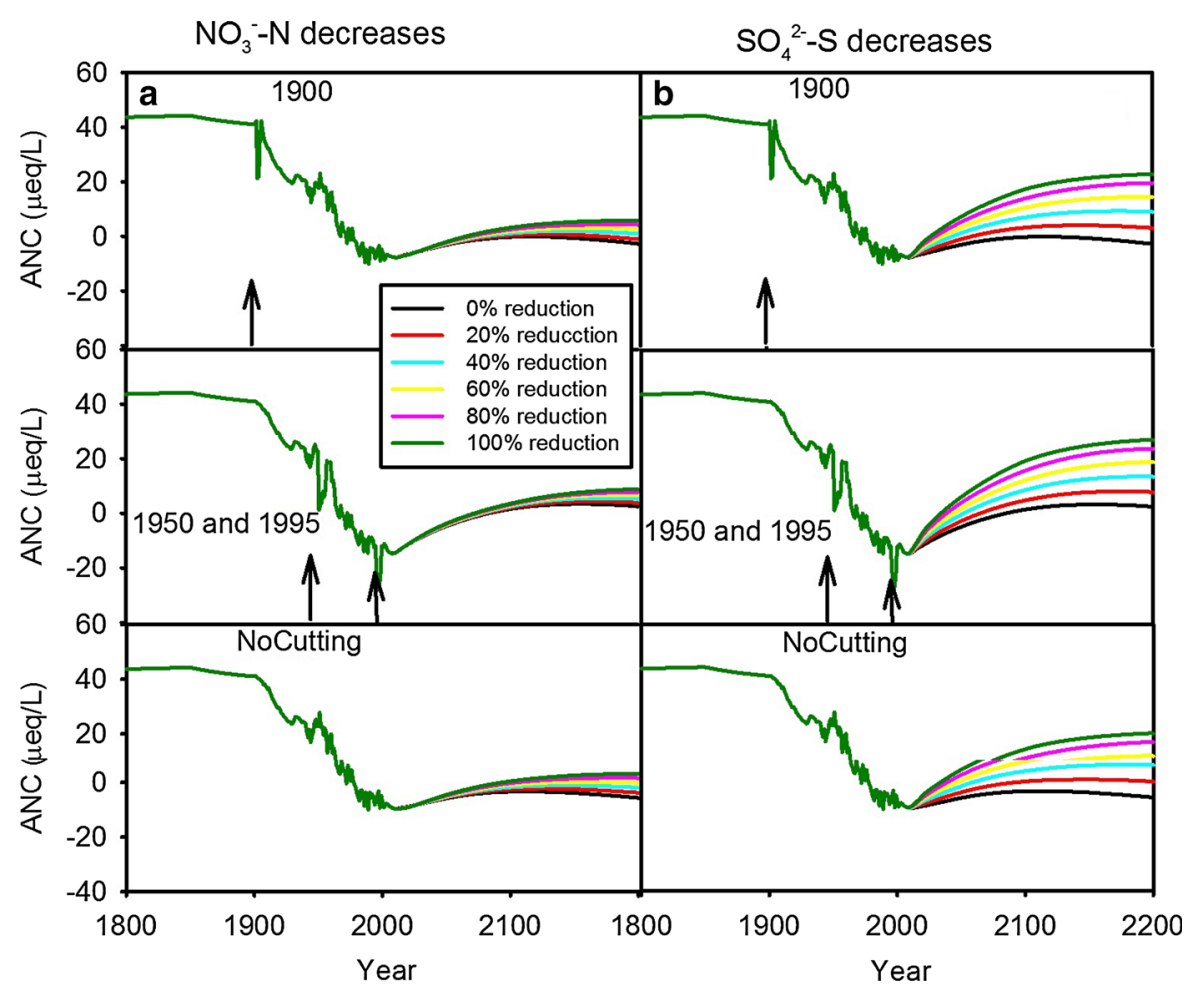

acidification resulting in lake ANC of $-14.7 \mu \mathrm{eq} / \mathrm{L}$ in 2005 and a minimum soil \% BS of $3.9 \%$ (Fig. 6). Although historical acidification is more pronounced under this more severe forest disturbance scenario, the extent of ANC recovery following decreases in $\mathrm{SO}_{4}{ }^{2-}$ or $\mathrm{NO}_{3}{ }^{-}$deposition is greater than under the less severe historical land disturbance scenarios. Under the severe historical disturbance scenario at steady-state (i.e., 2200), if $\mathrm{NO}_{3}{ }^{-}$deposition is decreased to preindustrial values, ANC values are projected to increase to $8.8 \mu \mathrm{eq} / \mathrm{L}$, slightly higher than the ANC achieved under the base case scenario $(5.7 \mu \mathrm{eq} / \mathrm{L})$ (Fig. 6). If $\mathrm{SO}_{4}{ }^{2-}$ deposition is decreased to pre-industrial values, ANC values are projected to increase to $32 \mu \mathrm{eq} / \mathrm{L}$, again slightly higher than the ANC achieved under the base case scenario (30 $\mu \mathrm{eq} / \mathrm{L})$ (Fig. 6).

Changes in the supply of naturally occurring organic acids

To examine the influence of the supply of naturally occurring organic acids, we alter the extent to which soil organic matter was decomposed to DOC in the model. In addition to the base-case scenario with a DOC concentration of $420 \mu \mathrm{mol} \mathrm{C} / \mathrm{L}$, simulations are also conducted under higher lake DOC concentration $(905 \mu \mathrm{mol} \mathrm{C} / \mathrm{L})$ and lower DOC concentration (125 $\mu \mathrm{mol} \mathrm{C/L}$ ) (Fig. 7) throughout the entire simulation period. These latter two scenarios are considered to be representative of high and low DOC lakes in the Adirondacks. The supply of naturally occurring organic acids alters lake ANC as well as $\mathrm{pH}$ buffering capacity due to occurrence of organic functional groups, particularly strongly acidic functional groups (Driscoll et al. 1994). In comparison with the projected pre-industrial ( 1850) ANC of $43 \mu \mathrm{eq} / \mathrm{L}$ for the basecase, under the scenario of elevated supply of naturally occurring organic acids, the pre-industrial ANC decreases to $34 \mu \mathrm{eq} / \mathrm{L}$. Under the scenario of limited supply of naturally occurring organic acids $(125 \mu \mathrm{mol}$ $\mathrm{C} / \mathrm{L}$ ), the pre-industrial ANC increases to $52 \mu \mathrm{eq} / \mathrm{L}$ (Fig. 7). This difference in ANC $( \pm 9 \mu \mathrm{eq} / \mathrm{L})$ due to variation in DOC supply to Constable Pond-watershed remains constant through the hindcast and all forecast simulations.

Hydraulic residence time

To evaluate the extent to which in-lake retention of strong acid anions could influence historical 
Fig. 7 Simulations of ANC at Constable Pond over 1800-2200 under scenarios of high, ambient and low DOC concentrations (i.e., $1000,423,100 \mu \mathrm{mol} \mathrm{C} / \mathrm{L}$ ) in response to past and hypothetical future decreases in $\mathrm{NO}_{3}{ }^{-}$(a) and $\mathrm{SO}_{4}{ }^{2-}$ (b) deposition

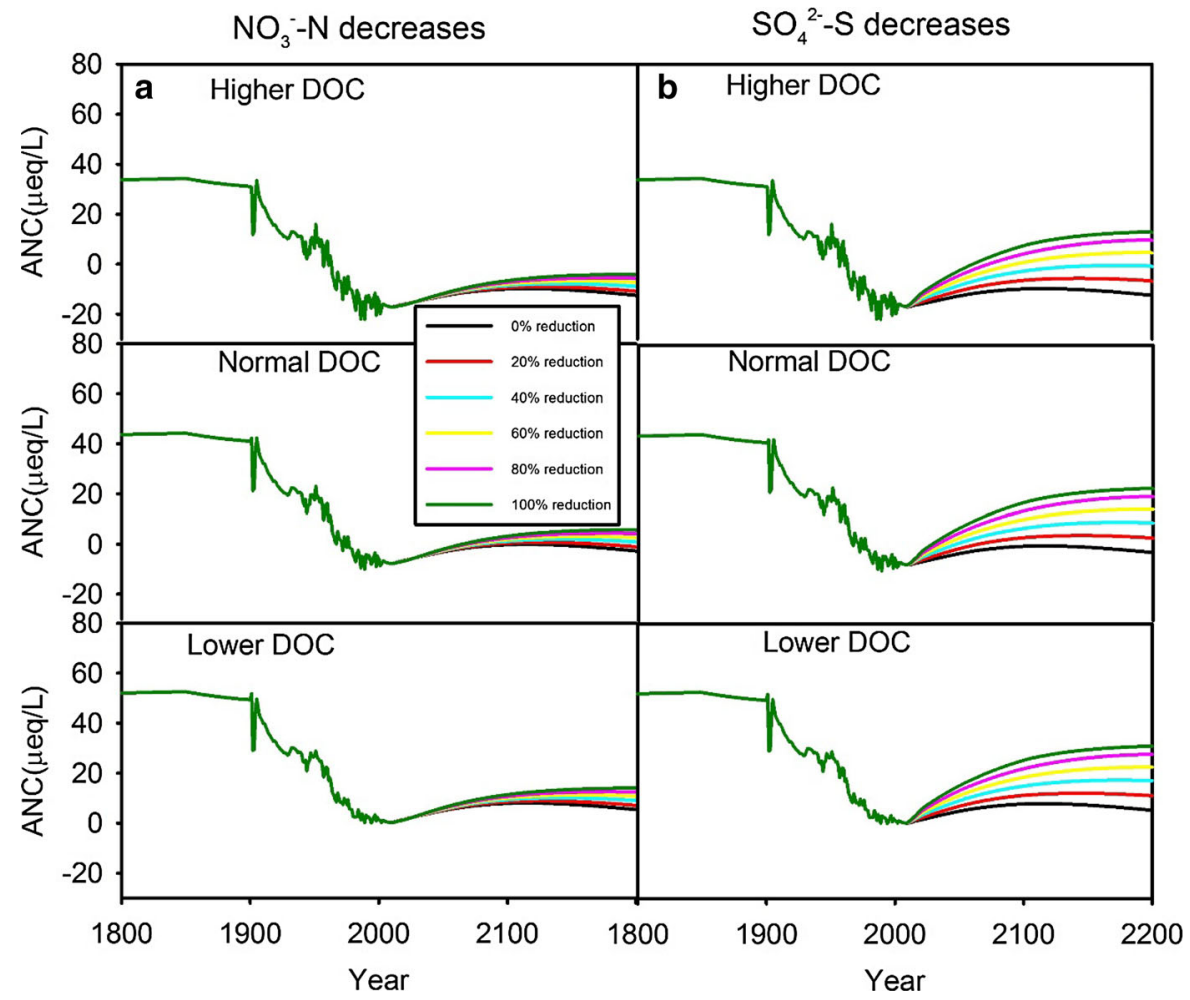

acidification and the recovery from acid deposition, we apply two scenarios of hypothetical simulations of longer HRT (0.6 and 6 years), in addition to the basecase ( 0.06 year). Under the base-case scenario, there is a short-term acidification event that follows the historical clear-cut $(\sim 1900)$. Under conditions of longer HRT rather than an acidification event after the historical clear-cut, an "alkalization" event is evident (Fig. 8). After the simulated historical clear-cut in 1900 , there is a long-term increase in leaching of $\mathrm{NO}_{3}{ }^{-}$and base cations from the watershed to Constable Pond. Under the scenarios of longer HRT, this $\mathrm{NO}_{3}{ }^{-}$input is retained in the lake while base cations are not retained, resulting in marked in-lake production of ANC. More diffuse alkalization events are also simulated for the periods 1946-1956 and 1988-1998 due to conditions of elevated $\mathrm{NO}_{3}{ }^{-}$ leaching that occur periodically due to variations in meteorological conditions. Finally the simulated minimum lake ANC in 2005 (-7.6 $\mu \mathrm{eq} / \mathrm{L}$ under the base case) increases with increases in HRT due to greater retention of $\mathrm{SO}_{4}{ }^{2-}$ and $\mathrm{NO}_{3}{ }^{-}(11.4 \mu \mathrm{eq} / \mathrm{L}$ for 0.6 year HRT; $20.1 \mu \mathrm{eq} / \mathrm{L}$ for 6 year HRT).

Projections of future changes in ANC with decreases in atmospheric $\mathrm{SO}_{4}{ }^{2-}$ and $\mathrm{NO}_{3}{ }^{-}$deposition show patterns of recovery that are considerably different under elevated HRT compared to the base case (Fig. 8). Increasing HRT greatly increases the ANC value achieved in recovery for a given future decreases in atmospheric $\mathrm{SO}_{4}{ }^{2-}$ deposition. In contrast, future decreases in atmospheric $\mathrm{NO}_{3}{ }^{-}$deposition have an acidifying effect relative to the base case. This counterintuitive response is due to the higher mass transfer coefficient for in-lake retention of $\mathrm{NO}_{3}{ }^{-}$than for $\mathrm{SO}_{4}{ }^{2-}$. Under higher loading of $\mathrm{NO}_{3}{ }^{-}$from the watershed to the lake, there is greater in-lake retention of $\mathrm{NO}_{3}{ }^{-}$that results in equivalent production of ANC. Similarly, decreases in atmospheric $\mathrm{NO}_{3}{ }^{-}$deposition result in decreases in $\mathrm{NO}_{3}{ }^{-}$leaching from the watershed, less in-lake retention of $\mathrm{NO}_{3}{ }^{-}$and lower production of ANC.

\section{Discussion}

Comparison of effects of changes in $\mathrm{SO}_{4}{ }^{2-}$ and $\mathrm{NO}_{3}{ }^{-}$deposition

Results of the model simulations demonstrate that the recovery of lake ANC in Constable Pond is 
Fig. 8 Simulations of ANC for Constable Pond over 1800-2200 under scenarios of three different hydraulic residence times $(6,0.6$ and 0.06 year) in response to past and hypothetical future decreases in $\mathrm{NO}_{3}{ }^{-}$(a) and $\mathrm{SO}_{4}^{2-}$ (b) deposition

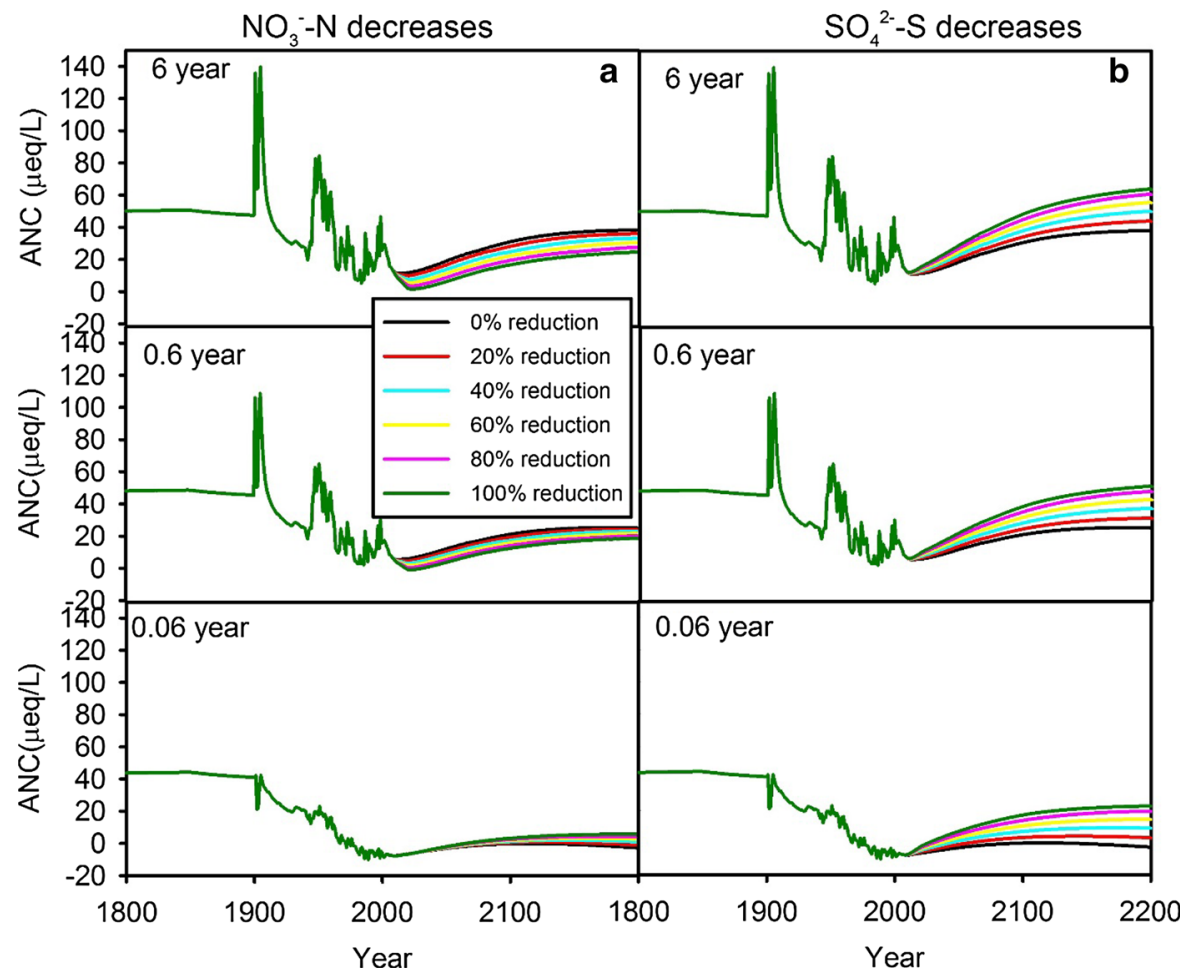

accomplished more effectively by equivalent decreases in $\mathrm{SO}_{4}{ }^{2-}$ deposition compared to $\mathrm{NO}_{3}{ }^{-}$deposition under all of the hypothetical conditions shown for this lake. Atmospheric $\mathrm{SO}_{4}{ }^{2-}$ deposition is the main contributor to acidification of soil and surface waters in the northeastern U.S. (Church et al. 1989). Constable Pond watershed has received greater historical total $\mathrm{SO}_{4}{ }^{2-}$ deposition (dry and wet; currently $310 \mathrm{eq} /$ ha-year) than $\mathrm{NO}_{3}{ }^{-}$deposition (dry and wet; 200 eq/ ha-year; Fig. 2). Atmospheric deposition of $\mathrm{SO}_{4}{ }^{2-}$ is transported more conservatively through lake-watersheds of the Adirondacks than $\mathrm{NO}_{3}{ }^{-}$and therefore contributes more effectively to the leaching of cations from the ecosystem and the resulting acidification. $\mathrm{N}$ saturation is the condition that occurs when the external supply of $\mathrm{N}$ to a watershed exceeds the demand for $\mathrm{N}$ by plants, microbes and soil within the watershed (Stoddard 1994; Aber et al. 1989). Studies have shown that forest watershed ecosystems in the eastern U.S, have generally not reached N saturation, and have capacity to retain ambient $\mathrm{N}$ inputs (Stoddard 1994; Driscoll et al. 2003). The period for a forest ecosystem to reach $\mathrm{N}$ saturation is on the order of multiple decades to centuries (Driscoll et al. 2003).
Model calculations show that lake-watershed $\mathrm{N}$ retention diminishes over time due to decreasing capacity to retain $\mathrm{N}$ with forest maturation under hypothetically constant climate and deposition, although a condition of $\mathrm{N}$ saturation is not attained by the end of the simulation period. Over the longterm the tendency for increases in $\mathrm{NO}_{3}{ }^{-}$leaching within the watershed, increases the extent to which controls on atmospheric $\mathrm{N}$ deposition result in increases in lake ANC.

Land disturbance effects

Simulation results suggest that past forest cutting has enhanced historical acidification associated with acid deposition over the short term (a few years). Following forest cutting around 1900 in the base case scenario, lake ANC decreases sharply for a few years due to high loss of $\mathrm{NO}_{3}{ }^{-}$(Figs. 3, 6). The mobilization of $\mathrm{Ca}^{2+}$ from soil cation exchange sites to water associated with the leaching of $\mathrm{NO}_{3}{ }^{-}$attenuates the pulse decrease in ANC. Forest cutting decreases plant uptake in the short term. As soil $\mathrm{N}$ mineralization proceeds in the absence of vegetative uptake the 
supply of available $\mathrm{NH}_{4}{ }^{+}$is nitrified, allowing for elevated $\mathrm{NO}_{3}{ }^{-}$losses in drainage water (Aber and Driscoll 1997). In addition to these short-term effects, model simulations suggest that forest cutting can enhance the susceptibility of acid-sensitive watersheds over the long-term. The removal of biomass from harvesting and associated leaching immediately following decreases the forest ecosystem pool of nutrient cations (in vegetation, soil organic matter and associated with the soil exchanger) and allows for greater soil and water acidification from acid deposition.

Model simulations suggest, however, that forest cutting can enhance the extent of ANC recovery over the long-term (i.e., multiple decades to centuries). Goodale and Aber (2001) evaluated long-term effects of logging and fire on northern hardwood forests in the eastern US and found that the old growth sites had higher nitrification rates and higher stream $\mathrm{NO}_{3}{ }^{-}$ concentrations compared with the historically disturbed sites. High nitrification rate and low watershed $\mathrm{N}$ retention is one possible explanation for relatively lower ANC under the no-historical land disturbance scenario when the model reaches steady state. ANC increases under historical forest cutting scenario due to greater retention of $\mathrm{N}$ inputs by the aggrading forest.

Supply of naturally occurring dissolved organic matter

Model simulations show that changes in the supply of DOM affects the acid-base status of Adirondack waters. In PnET-BGC, the acid-base character of DOM is modeled as a triprotic analog (Driscoll et al. 1994; Gbondo-Tugbawa et al. 2001). DOM has strongly acidic functional groups that consume ANC.

Adirondack lakes appear to be experiencing changes in DOM, at least in part in response to decreases in acid deposition. A large fraction of lakes have exhibited significant increases in DOC coincident with decreases in $\mathrm{SO}_{4}{ }^{2-}$ and $\mathrm{NO}_{3}{ }^{-}$and increases in $\mathrm{pH}$ and $\mathrm{ANC}$ (Driscoll et al. 2007). For example, DOC in Constable Pond has increased from about $400 \mu \mathrm{mol} \mathrm{C} / \mathrm{L}$ when monitoring was initiated in 1982 to about $500 \mu \mathrm{mol} \mathrm{C} / \mathrm{L}$ currently. This phenomenon is consistent with the observations for many monitored surface waters in Europe and North America (Monteith et al. 2007), including the Adirondacks (Driscoll et al. 2007).

Increases in DOC have important implications for the future structure and function in downstream aquatic ecosystems. The attenuation of light and the thermal stratification of Adirondack lakes is strongly regulated by DOM (Effler et al. 1985). Also DOM is apparently an important energy source for unproductive Adirondack lakes (Adams et al. 2009). The acidic characteristics of DOM can alter the $\mathrm{pH}$ and ANC of Adirondack lakes (Driscoll et al. 1994).

While PnET-BGC is parameterized to simulate ambient concentrations of DOC and to depict its effects on the acid-base chemistry of surface waters (Gbondo-Tugbawa et al. 2001), it is not able to represent the widespread observation of the compensatory increase in DOM to decreases in acid deposition because the model does not consider decreases in the partitioning of organic matter with soil that appears to occur with decreases in acid deposition and increases in soil $\mathrm{pH}$. Given the ongoing decreases in acid deposition and the need to project accurate targets for ecosystem recovery from acid deposition, this would seem to be a critical need for future modeling efforts to project TLs and CLs in acid impacted watersheds.

\section{In-lake processes}

In-lake process are complex biogeochemical phenomena, but generally the net effect of an alkalization process (Schindler et al. 1985; Kilham 1982). The major retention mechanism for $\mathrm{SO}_{4}{ }^{2-}$ retention is reduction in sediment and for $\mathrm{NO}_{3}{ }^{-}$retention is algal uptake or denitrification (Kelly et al. 1987). Longer lake HRT allows for greater mass transfer of $\mathrm{NO}_{3}{ }^{-}$or $\mathrm{SO}_{4}{ }^{2-}$ to lake sediments and greater production of ANC for the lake-watershed.

The short-term fluctuation in $\mathrm{NO}_{3}{ }^{-}$and $\mathrm{ANC}$ around 1900 illustrates some of the intricacies of inlake process (Fig. 8). Whether in-lake processes generate or consume ANC depends on the supply of major anions and major cations and the specific HRT. The projection of changes in ANC values around 1900 in Constable Pond shifted from negative under low HRT to positive values at longer HRT. This pattern was attributable to the retention of $\mathrm{SO}_{4}{ }^{2-}$ and particularly $\mathrm{NO}_{3}{ }^{-}$following the clear-cut (Fig. 8). Previous studies have indicated that in-lake $\mathrm{NO}_{3}{ }^{-}$or $\mathrm{SO}_{4}{ }^{2-}$ removal increases with increases in HRT (Kelly et al. 1987). Based on this observation, a larger amount of $\mathrm{NO}_{3}{ }^{-}$or $\mathrm{SO}_{4}{ }^{2-}$ leached from the watershed is removed through in-lake processes under the longer HRT scenario than the shorter HRT scenario. 
The greater mass transfer coefficient for in-lake $\mathrm{NO}_{3}{ }^{-}$retention as compared with $\mathrm{SO}_{4}{ }^{2-}$ retention has implications for strategies of achieving lake ANC recovery. Because many Adirondack lakes are characterized by short HRTs, in-lake processes are not a critical consideration in the recovery of these ecosystems. However, in-lake processes can be important in larger lakes or lakes with smaller watersheds where these processes are manifested. Greater increases in ANC can be achieved in response to decreases in $\mathrm{SO}_{4}{ }^{2-}$ deposition in lakes with longer HRTs than shorter HRTs due to greater in-lake retention of $\mathrm{SO}_{4}{ }^{2-}$. In contrast, decreases in $\mathrm{NO}_{3}{ }^{-}$deposition are projected to result in lesser increases in ANC in lakes with longer HRTs due to the relatively effective retention of $\mathrm{N}$ by the watershed, which diminishes inputs of $\mathrm{NO}_{3}{ }^{-}$to the lake. This differential response of ANC increase to equivalent decreases in $\mathrm{SO}_{4}{ }^{2-}$ compared to $\mathrm{NO}_{3}{ }^{-}$deposition is an additional consideration. It influences the effectiveness of decreases in $\mathrm{SO}_{4}{ }^{2-}$ deposition in facilitating recovery of Adirondack lakes.

\section{Conclusions}

We determined the CLs and TLs of $\mathrm{SO}_{4}{ }^{2-}$ and $\mathrm{NO}_{3}{ }^{-}$ for Constable Pond. We also assess the factors that affect the acidification and recovery of the surface water in the Adirondack region, yielding the following conclusions:

1. Lake ANC increases in response to decreases in $\mathrm{SO}_{4}{ }^{2-}, \mathrm{NO}_{3}{ }^{-}$or $\mathrm{NH}_{4}{ }^{+}$deposition. However, greater increases in ANC occur in response to decreases in $\mathrm{SO}_{4}{ }^{2-}$ deposition as compared with an equivalent decrease in $\mathrm{NO}_{3}{ }^{-}$deposition and somewhat greater increases in ANC occur in response to decreases in $\mathrm{NH}_{4}{ }^{+}$deposition as compared with an equivalent decrease in $\mathrm{NO}_{3}{ }^{-}$ deposition.

2. Forest cutting disturbance leads to short-term $\mathrm{NO}_{3}{ }^{-}$losses from watersheds. Model simulations show that forest cutting can enhance acidification due to the removal of nutrient cations associated with the removal of forest biomass. However, over the long-term, forest cutting can enhance recovery from acid deposition due to the greater retention of atmospheric $\mathrm{N}$ deposition in an aggrading forest ecosystem.
3. DOM supply affects the acid-base status of surface water. The greater recovery of ANC can be achieved in lakes with lower DOC concentrations as compared with higher DOC concentrations. The inability of PnET-BGC and other acidification models to depict the compensatory response of watershed DOM to decreases in acid deposition may limit our ability to establish accurate targets for acidification and recovery.

4. In-lake processes affect ANC and the extent of recovery of Adirondack lakes with longer HRTs. For lakes with longer HRTs, decreases in $\mathrm{SO}_{4}{ }^{2-}$ deposition result in greater ANC values as compared with decreases in $\mathrm{NO}_{3}{ }^{-}$deposition due to more efficient watershed retention of $\mathrm{NO}_{3}{ }^{-}$.

Acknowledgments This research was supported by a contract from the New York State Energy Research and Development Authority (NYSERDA) to E\&S Environmental Chemistry, Inc. (Agreement 10567). NYSERDA has not reviewed the information contained herein, and the opinions expressed in this manuscript do not necessarily reflect those of NYSERDA or the State of New York.

Open Access This article is distributed under the terms of the Creative Commons Attribution 4.0 International License (http:// creativecommons.org/licenses/by/4.0/), which permits unrestricted use, distribution, and reproduction in any medium, provided you give appropriate credit to the original author(s) and the source, provide a link to the Creative Commons license, and indicate if changes were made.

\section{References}

Aber JD, Driscoll CT (1997) Effects of land use, climate variation, and $\mathrm{N}$ deposiiton on $\mathrm{N}$ cyclying and $\mathrm{C}$ storage in northern hardwood forest. Glob Biogeochem Cycles 11:639-648

Aber JD, Freuder R (2000) Variation among solar radiation data sets for the eastern U.S. and its effects on predictions of forest production and water yield. Clim Res 15:33-43

Aber JD, Nadelhoffer KJ, Steudler P, Melillo J (1989) Nitrogen saturation in northern forest ecosystems. Bioscience 39:378-386

Aber JD, Ollinger SV, Driscoll CT (1997) Modeling nitrogen saturation in forest ecosystems in response to land use and atmospheric deposition. Ecol Model 101:61-78

Adams RM, Twiss MR, Driscoll CT (2009) Patterns of mercury accumulation among seston in lakes of the Adirondack, New York. Environ Sci Technol 43:4836-4842

Burns DA, Blett T, Haeuber R, Pardo L (2008) Critical Loads as a policy tool for protecting ecosystems from the effects of air pollutants. Front Ecol Environ 6:156-159 
Chen L, Driscoll CT (2004) An evaluation of processes regulating spatial and temporal patterns in lake sulfate in the Adirondack region of New York. Glob Biogeochem Cycles 18:GB3024

Chen L, Driscoll CT (2005) A two-layer model to simulate variations in surface water chemistry draining a northern forest watershed. Water Resour Res. doi:10.1029/ 2004WR003625

Chen L, Driscoll CT, Gbondo-Tugbawa S, Mitchell MJ, Murdoch PS (2004) The application of an integrated biogeochemical model (PnET-BGC) to five forested watersheds in the Adirondack and Catskill regions of New York. Hydrol Process 18:2631-2650

Church MR, Thornton KW, Shaffer PW, Stevens DL, Rochelle BP, Holdren GR (1989) Future effects of long-term sulfur deposition on surface water chemistry in the Northeast and southern Blue Ridge Province (EPA/600/3-89/061). US Environmental Protection Agency, Washington, DC

Cronan CS, Conlan JC, Skibinski S (1987) Forest vegetation in relation to surface-water chemistry in the north branch of the Moose River, Adirondack Park, New York. Biogeochemistry 3:121-128

Driscoll CT, Cowling EB, Grennfelt P, Galloway J, Dennis R (2010) Integrated assessment of ecosystem effects of atmospheric deposition: Lessons available to be learned. Environ Manage 2010:6-13

Driscoll CT, Yatsko CP, Unangst FJ (1987) Longitudinal and temporal trends in the water chemistry of the North Branch of the Moose River. Biogeochemistry 3:37-62

Driscoll CT, Lehtinen MD, Sullivan TJ (1994) Modeling the acid-base chemistry of organic solutes in Adirondack, NY, lakes. Water Resour Res 30:297-306

Driscoll CT, Lawrence GB, Bulger AJ, Butler TJ, Cronan CS, Eagar C, Lambert K, Likens GE, Stoddard JL, Weathers KC (2001) Acidic deposition in the Northeastern United States: Sources and Inputs, Ecosystem Effects, and Management Strategies. Bioscience 51:180-198

Driscoll CT, Driscoll KM, Roy KM, Mitchell MJ (2003) Chemical response of lakes in the Adirondack region of New York to declines in acidic deposition. Environ Sci Technol 37:2036-2042

Driscoll CT, Driscoll KM, Roy KM, Dukett J (2007) Changes in the chemistry of lakes in the Adirondack region of New York following declines in acidic deposition. Appl Geochem 22:1181-1188

Effler SW, Schafran GC, Driscoll CT (1985) Partitioning light attenuation in an acidic lake. Can J Fish Aquat Sci 42:1707-1711

Fakhraei H, Driscoll CT, Selvendiran P, DePinto JV, Bloomfield J, Quinn S, Rowell HC (2014) Development of a total maximum daily load (TMDL) for acid-impaired lakes in the Adirondack region of New York. Atmos Environ 95:277-287

Gbondo-Tugbawa SS, Driscoll CT (2001) Evaluation of an integrated biogeochemical model (PnET-BGC) at a northern hardwood forest ecosystem. Water Resour Res 37:1057-1070

Gbondo-Tugbawa SS, Driscoll CT, Aber JD, Likens GE (2001) Evaluation of an integrated biogeochemical model (PnETBGC) at a northern hardwood forest ecosystem. Water Resour Res 37:1057-1070
Goodale CL, Aber JD (2001) The long-term effects of land-use history on nitrogen cycling in northern hardwood forests. Ecol Appl 11:253-267

Greaver TL, Sullivan TJ, Herrick JD, Barber M, Baron JS, Cosby BJ, Deerhake M, Dennis R, Dubois JD, Goodale CE, Herlihy AT, Lawrence GB, Liu LL, Lynch J, Novak K (2012) A synthesis of the ecological effects of air pollution from nitrogen and sulfur in the United States. Front Ecol Environ 10:365-372

Ito M, Mitchell MJ, Driscoll CT (2002) Spatial patterns of precipitation quantity and chemistry and air temperature in the Adirondack region of New York. Atmos Environ 36:1051-1062

Janssen PHM, Heuberger PSC (1995) Calibration of processoriented models. Ecol Model 83:55-66

Juice SM, Fahey TJ, Siccama TG, Driscoll CT, Denny E, Eagar C, Cleavitt NL, Minocha R, Richardson AD (2006) Response of sugar maple to calcium addition to northern hardwood forest. Ecology 87:1267-1280

Kahl JS, Stoddard JL, Haeuber R, Paulsen SG, Birnbaum R, Deviney FA, Webb JR, DeWalle DR, Sharpe W, Driscoll CT (2004) Have US surface waters responded to the 1990 Clean Air Act amendments? Environ Sci Technol 38:484A-490A

Kalbitz K, Solinger S, Park JH, Michalzik B, Marzner E (2000) Controls on the dynamic of dissolved organic matter in soils: a review. Soil Sci 165:277-304

Kelly CA, Rudd JWM, Hesslein RH, Schindler DW, Dillon PJ, Driscoll CT, Gherini SA, Hecky RE (1987) Prediction of biological acid neutralization in acid-sensitive lakes. Biogeochemistry 3:129-140

Kilham P (1982) Acid precipitation: its role in the alkalization of a lake in Michigan. Limnol Oceanogr 27:856-867

Kretser W, Gallagher J, Nicholetter J (1989) Adirondack lake study, 1984-1987: an evaluation of fish communities and water chemistry. Adirondack Lakes Survey Corporation, Ray Brook, NY

Lovett GM, Tear TH, Evers DC, Findlay SEG, Cosby BJ, Dunscomb JK, Driscoll CT, Weathers KC (2009) Effects of air pollution on ecosystems and biological diversity in the Eastern United States. Ann N Y Acad Sci 1162:99-135

McNeil BE, Read JM, Driscoll CT (2006) Foliar nitrogen responses to elevated atmospheric nitrogen deposition in nine temperate forest canopy species. Environ Sci Technol 41:5191-5197

Monteith DT, Stoddard JL, Evans CD, de Wit HA, Forsius M, Høgåsen T, Wilander A, Skjelkvåle BL, Jeffries DS, Vuorenmaa J et al (2007) Dissolved organic carbon trends resulting from changes in atmospheric deposition chemistry. Nature 450:537-540

Nilsson J, Grenfelt P (1988) Critical loads for sulfur and nitrogen. UNECE/Nordic Council workshop report, Skokloster, Sweden. March 1988. Nordic Council of Ministers, Copenhagen pp 418

Nizich SV, Misenheimer D, Pierce T, Pope A, Carlson P (1996) National air pollutant emission trends, 1900-1995. US Environmental Protection Agency, EPA-454/R-96-007, Office of Air Quality, Research Triangle Park

Porter E, Blett T, Potter DU, Huber C (2005) Protecting resources on federal lands: implications of critical loads for 
atmospheric deposition of nitrogen and sulfur. BioScience 55:603-612

Pourmokhtarian A, Driscoll CT, Campbell JL, Hayhoe K (2012) Modeling potential hydrochemical responses to climate change and increasing $\mathrm{CO} 2$ at the Hubbard Brook Experimental Forest using a dynamic biogeochemical model (PnET-BGC). Water Resour Res. doi:10.1029/ 2011WR011228

Schindler DW, Mills KH, Malley DF, Findlay S, Shearer JA, Davies IJ, Turber MA, Lindsey GA, Cruikshank DR (1985) Long-term ecosystem stress: effects of years of experimental acidification. Can J Fish Aqua Sci 37:342-354

Shepard JP, Mitchell MJ, Scott TJ, Zhang YM, Raynal DJ (1989) Measurements of wet and dry deposition in a northern hardwood forest. Water Air Soil Pollut 48:225238

Stoddard JL (1994) Long-term changes in watershed retention of nitrogen: its causes and aquatic consequences. American Chemical Society, Washington, DC

Sullivan TJ, Cosby BJ, Driscoll CT, McDonnell TC, Herlihy AT, Burns DA (2012) Target loads of atmospheric sulfur and nitrogen deposition for protection of acid sensitive aquatic resources in the Adirondack Mountains, New York. Water Resour Res 48(W01547):16. doi:10.1029/2011 WR011171
Thomas RQ, Canham CD, Weathers KC, Goodale CL (2009) Increases tree carbon storage in response to nitrogen deposition in the US. Nat Geosci 3:13-17

van Breemen N, Mulder J, Driscoll CT (1983) Acidification and alkalization of soils. Plant Soil 75:283-308

Waller K, Driscoll CT, Lynch J, Newcomb D, Roy K (2012) Long-term recovery of lakes in the Adirondack region of New York to decreases in acidic deposition. Atmos Environ 46:56-64

Zhai J, Driscoll CT, Sullivan TJ, Cosby BJ (2008) Regional application of the PnET-BGC model to assess historical acidification of Adirondack lakes. Water Resour Res. doi:10.1029/2006WR005532

Zhou Q, Driscoll CT, Sullivan TJ (2015) Responses of 20 lakewatersheds in the Adirondack region of New York to historical and potential future acidic deposition. Sci Total Environ 511:186-194. doi:10.1016/j.scitotenv.2014.12. 044

Zsolnay A (1996) Dissolved humus in soil water. In: Piccolo A (ed) Humic Substances in Terrestrial Ecosystems. Elsevier, Amsterdam, pp 171-223 